\title{
Development of Novel Anti-Cd20 Monoclonal Antibodies and Modulation in Cd20 Levels on Cell Surface: Looking to Improve Immunotherapy Response
}

\author{
Vijay Singh ${ }^{1 *}$, Damodar Gupta ${ }^{1 *}$ and Alexandru Almasan ${ }^{2,3}$ \\ ${ }^{1}$ Metabolic Cell Signaling Research, Institute of Nuclear Medicine \& Allied Sciences, Brig SK Mazumdar Marg, Timarpur, Delhi, 110054, India \\ ${ }^{2}$ Department of Radiation Oncology, Taussig Cancer Institute, Cleveland Clinic, Cleveland, OH 44195, USA \\ ${ }^{3}$ Department of Cancer Biology, Lerner Research Institute, Cleveland Clinic, Cleveland, OH 44195, USA
}

\begin{abstract}
Rituximab has been revolutionized and validated CD20 targeting monoclonal antibody. Although, it is widely used for lymphoma therapy and many patients have been benefited. However significant numbers of patients are refractory or developed resistance to current therapies due to low level of CD20 expression and/or availability on cells surface. Thus development of novel anti-CD20 mAbs with great cell killing ability and enhance CD20 levels on cell surface can potentially exploit lymphoma therapy. In this scenario, we are summarizing the recently developed mAbs against CD20 and compounds that have ability to induce CD20 expression at significant level. We also are providing information regarding combination strategy for use of radiation and anti-CD20 mAbs in vitro. However it will need to be determined by rigorous at pre-clinical and clinic testing. We hope this review will be beneficial for current research in the area of immunotherapy or radio-immunotherapy.
\end{abstract}

Keywords: NHL; Antibody dependent cellular cytotoxicity; Complement dependent cytotoxicity; Programmed Cell Death; Radiation; CD20

Abbreviations: ADCC: Antibody-Dependent Cellular Cytotoxicity; ADCP: Antibody-Dependent Cellular Phagocytosis; AIDS: Acquired Immuno-Deficiency Syndrome; ALCL: Anaplastic Large Cell Lymphoma; ALL: Acute Lymphoblastic Leukemia; CD: Clusters of Differentiation; CR: Complete Response; CDC: ComplementDependent Cytotoxicity; CDRs: Complementarity Determining Regions; CLL: Chronic Lymphocytic Leukemia; CNS: Central Nervous System; DLBCL: Diffuse Large B-cell Lymphoma; EATL: EnteropathyAssociated Intestinal T-Cell Lymphoma; ERK: Extracellular Regulated Kinase; ETTL: Enteropathy Type T-Cell Lymphoma; FDA: Food and Drug Administration; FL: Follicular Lymphoma; HCL: Hairy Cell Leukemia; HIV: Human Immunodeficiency Virus; HL : Hodgkin lymphoma; HTLV-1: Human T-Lymphotropic Virus-1; IARC: International Agency for Research on Cancer; IgM: Immunoglobulin M; ITCL: Intestinal T-Cell Lymphoma; mAb: Monoclonal Antibody; MALT: Mucosa Associated Lymphoid Tissue; MAPK: Mitogen Activated Protein Kinase; MZL: Marginal Zone Lymphoma; NA: Not Available; NHL: Non-Hodgkin Lymphoma; NK cells: Natural Killer Cells; OFA: Ofatumumab; ORR: Overall Response Rate; PCD: Programmed Cell Death; PTCL: Peripheral T-Cell Lymphomas; RA: Rheumatoid Arthritis; R-CHOP: Rituximab-Cyclophosphamide Hydroxydaunorubicin Oncovin Prednisone; RNA: Ribonucleic Acid; RT: Radiation Therapy; SLL: Small Lymphocytic Lymphoma; SMIP: Small Modular Immuno-Pharmaceutical; UK: United Kingdom; US: United States; WHO: World Health Organization

\section{Introduction}

Cancer remain is a global concern and great challenge to medical management. It has emerged as the second leading cause of death globally after cardiovascular diseases. The International Agency for Research on Cancer (IARC) recently estimated that 8.2 million deaths worldwide were due to cancer with 14.1 million new cases per year being reported worldwide [1]. In India, deaths from the disease have increased by $60 \%$ according to the 'Global Burden of Cancer-2013' report [2]. Among them non-Hodgkin lymphoma is the tenth most common type of cancer in the world. Approximately 71,850 new cases and 19,790 deaths were reported due to non-Hodgkin lymphoma in 2015 (Surveillance, Epidemiology and End Results Program 2015).

It is a type of blood cancer that occurs when lymphocytes begin behaving abnormally. Lymphocytes are white blood cells that protect the body from infection and disease. Abnormal lymphocytes may divide faster than normal cells or they may live longer than they are supposed to. Lymphoma may develop in many parts of the body such as the lymph nodes, spleen, bone marrow, blood or other organs of the human body.

There are two main types of lymphomas:

- Hodgkin lymphoma (HL): There are 6 types of HL an uncommon form of lymphoma that involves the Reed-Sternberg cells.

- Non-Hodgkin lymphoma (NHL): There are more than 61 types of NHL some of which are more common than others. In other words any lymphoma that does not involve Reed-Sternberg cells is classified as non-Hodgkin lymphoma.

Classification of non-Hodgkin lymphoma (NHL) can be quite

*Corresponding authors: Vijay Singh, High Throughput Screening \& Gene Expression Laboratory, Metabolic Cell Signaling Research, Institute of Nuclear Medicine \& Allied Sciences, Brig SK Mazumdar Marg, Timarpur, Delhi, 110054 India, Tel: 919540641620; E-mail: vijay_7july@yahoo.com

Dr. Damodar Gupta, High Throughput Screening \& Gene Expression Laboratory, Metabolic Cell Signaling Research, Institute of Nuclear Medicine \& Allied Sciences Brig SK Mazumdar Marg, Timarpur, Delhi, 110054, India, Tel: 011-23905370; Fax No.011-23919509; E-mail: damodar.gupta@gmail.com

Received October 21, 2015; Accepted November 17, 2015; Published November 24, 2015

Citation: Singh V, Gupta D, Almasan A (2015) Development of Novel AntiCd20 Monoclonal Antibodies and Modulation in Cd20 Levels on Cell Surface: Looking to Improve Immunotherapy Response. J Cancer Sci Ther 7: 347-358. doi:10.4172/1948-5956.1000373

Copyright: $\odot 2015$ Singh V, et al. This is an open-access article distributed unde the terms of the Creative Commons Attribution License, which permits unrestricted use, distribution, and reproduction in any medium, provided the original author and source are credited. 
confusing (even for doctors) because there are so many types and several different organs are involved. The most recent WHO classification is based on microscopic observations, the chromosome features of the lymphoma cells and the presence of certain proteins on the surface of the cells

o B-cell lymphomas: B-cell lymphomas make up most (about 85\%) of non-Hodgkin lymphomas in the United States (http:// www.cancer.org/cancer/non-hodgkinlymphoma).

o T-cell lymphomas: T-cell lymphomas make up less than $15 \%$ of non-Hodgkin lymphomas in the United States. There are many types of T-cell lymphoma but they are all fairly rare (http:// www.cancer.org/cancer/non-hodgkinlymphoma).

Doctors put non-Hodgkin lymphomas into two groups depending on how quickly they are likely to grow and spread (Table 1).

- Low grade (indolent): These tend to grow very slowly

- High grade (aggressive): These tend to grow more quickly

Currently different treatment modalities are used for treatment of cancer for instance surgery, radiation therapy, chemotherapy, and immunotherapy (targeted immunotherapy). Traditionally radiation therapy (RT) plays an important role in the management of NHL. RT alone may be used as curative treatment for stages I and II in patients with indolent NHL. For the more extensive and aggressive conditions RT is used in combination with chemotherapeutic substances. While indolent and aggressive NHLs are responsive to RT and chemotherapy 50\%$70 \%$ of patients are relapsed $[3,4]$. Most side effects are associated with conventional therapies due to the non-specific nature of the treatments. Thus, there is a constant need for development of novel therapeutic strategies or approaches that may improve the outcome of NHL patients. Therefore, targeted immunotherapy is right option to improve clinical responses with decreasing toxicity. Targeted immunotherapy in cancer involves the administration of a substances which specifically interact with a molecules which may be directly or indirectly involved in oncogenesis [5]. These are tumor associated antigens which expressed on the cell surface, soluble factors, extracellular matrix proteins and proteins associated with vascularization of tumors. The expression of these antigens should ideally be limited to only cancerous cells to decrease any side effects which may results from targeting of normal cells.

\section{Immunotherapy/ Radio-immunotherapy}

The concept of targeted immunotherapy was known almost a century before. Paul Ehrlich (1854-1915) the founder of immunology discovered a 'magic bullet' on the surface of an infected cell which able to selectively deliver a toxin to the bacterium inside the cell while sparing other tissues. This led to a discovery of therapy for syphilis in the pre-penicillin era for which Ehrlich received a Nobel Prize in 1908 [6]. The concept of the 'magic bullet' was successfully exploited by Milstein and Kohler in 1975 [7]. He successfully produced monoclonal antibodies using hybridoma technology and got Novel Prize for their intense scientific work. After two decades the concept of a 'therapeutic magic bullet' for cancer therapy was exist in 1997 with the approval of rituximab (anti-CD20 chimeric monoclonal antibody) by the US FDA for relapsed and refractory indolent lymphoma [8]. This was the first achievement of immunotherapy to kill B-lymphocytes by the use of anti-CD20 monoclonal antibody against the B-cell specific human CD20 cells surface molecules. The parallel successes of rituximab two other CD20 mAbs (Zevalin and Bexxar) were conjugated with radioactive materials to boost their therapeutic responses. Ibritumomab tiuxetan (Zevalin) is a CD20 mAb coupled with the radioactive isotope yttrium-90 or indium-111. Tositumumab (Bexxar) labeled with iodine-131. Both antibodies were approved by US FDA in 2002 and 2003 respectively. These are widely used for the treatment of follicular lymphoma (FL) patients and other NHLs as a part of radioimmunotherapy $[9,10]$. After that various $m A b s$ have been raised against CD20 some of them have been approved for human use (Figure 1).

The clinical success of CD20-targeted immunotherapy is limited expression of CD20 molecules. It is specifically expressed on tumor cells;

Low grade $\mathrm{NHL}$

\begin{tabular}{|c|c|c|}
\hline S.No. & Types of NHL & Description \\
\hline 1. & Follicular lymphoma & $\begin{array}{l}\text { It is the most common type (25\%) of B-cell low grade lymphoma in the UK. About } 1 \text { out of } 5 \text { lymphomas in the United States } \\
\text { is follicular lymphoma. It mainly occurs in adults at site of lymph node and bone marrow over the age of } 50 \text {. Over time about } \\
1 \text { in } 3 \text { follicular lymphomas turns into a fast-growing diffuse B-cell lymphoma. }\end{array}$ \\
\hline 2. & Mantle cell lymphoma & $\begin{array}{l}\text { Mantle cell lymphoma is a rare type of B-cell lymphoma. Mostly, It affects lymph node, bone marrow and often spleen over } \\
\text { people in their } 50 \text { s and } 60 \text { s age. It is also a B-cell lymphoma. However, it is classified as low grade but it grows quickly and } \\
\text { may be treated more like high grade lymphomas. }\end{array}$ \\
\hline 3. & Marginal zone B-cell lymphomas & $\begin{array}{l}\text { Marginal zone lymphomas are a group of slow growing B-cell lymphomas. They account } 5 \% \text { to } 10 \% \text { of lymphomas and tend } \\
\text { to occur in people over the age of } 60 \text {. The cells in these lymphomas look small under the microscope. } \\
\text { There are } 3 \text { types of marginal zone lymphoma. } \\
\text { 1. Extra-nodal marginal zone B-cell lymphoma is also called mucosa associated lymphoid tissue lymphoma or MALT } \\
\text { lymphoma-The most common site for MALT is the stomach due to infection of Helicobacter pylori. } \\
\text { 2. Nodal marginal zone lymphoma-It also called monocytoid B-cell lymphoma which occurs within the lymph nodes } \\
\text { sometimes can found in bone marrow. It makes up about } 2 \% \text { and more common in women than men over the age } \\
\text { of } 60 \text {. } \\
\text { 3. Splenic marginal zone lymphoma-This is a rare type of lymphoma which associated with hepatitis-C virus infection. } \\
\text { It starts in the spleen and can also be found in the bloodstream. This type makes up about } 1 \% \text { over the age } 50 \text {. }\end{array}$ \\
\hline 4. & $\begin{array}{l}\text { Small lymphocytic lymphoma } \\
\text { or } \\
\text { CLL }\end{array}$ & $\begin{array}{l}\text { It is also called chronic lymphocytic leukemia (CLL). It makes up about } 6 \% \text { in the UK. In theory, Chronic lymphocytic } \\
\text { leukemia is the term used for this condition if many of the abnormal cells are in the blood. Doctors call it small lymphocytic } \\
\text { lymphoma when the disease particularly occurs in lymph nodes. }\end{array}$ \\
\hline 5. & $\begin{array}{l}\text { Lymphoplasmacytic lymphomas } \\
\text { (including Wald Enstrom's } \\
\text { macroglobulinaemia) }\end{array}$ & $\begin{array}{l}\text { It accounts only } 1 \text { or } 2 \% \text { and specifically found in the bone marrow, lymph nodes, and spleen peoples over the age of } 65 . \text { It } \\
\text { is slightly more common in men than women. People with Wald Enstrom's macroglobulinaemia have a high level of a protein } \\
\text { called immunoglobulin } \mathrm{M}(\mathrm{lgM}) \text { in their blood. The protein makes the blood thicker. }\end{array}$ \\
\hline 6. & Skin lymphomas & A rare type of NHL is mycosis fungoid. It affects the skin and is also called cutaneous T-cell lymphoma. \\
\hline 7. & Hairy cell leukemia & $\begin{array}{l}\text { It is rare type B-cell lymphoma. It is typically found in the bone marrow and spleen and in the blood. Men are more likely to } \\
\text { get HCL than women and the average age is around } 50 .\end{array}$ \\
\hline 8. & $\begin{array}{l}\text { Primary central nervous system } \\
\text { (CNS) lymphoma }\end{array}$ & $\begin{array}{l}\text { This lymphoma usually involves the brain (called primary brain lymphoma) but it may also be found in the spinal cord, in } \\
\text { HIV infected people. }\end{array}$ \\
\hline
\end{tabular}


Citation: Singh V, Gupta D, Almasan A (2015) Development of Novel Anti-Cd20 Monoclonal Antibodies and Modulation in Cd20 Levels on Cell Surface: Looking to Improve Immunotherapy Response. J Cancer Sci Ther 7: 347-358. doi:10.4172/1948-5956.1000373

High grade NHL

\begin{tabular}{|c|c|c|}
\hline 1. & $\begin{array}{l}\text { Diffuse large B-cell lymphoma } \\
\text { (DLBCL) }\end{array}$ & $\begin{array}{l}\text { This is the most common type of non-Hodgkin lymphoma in the world. It can affect any age group but mostly occurs in } \\
\text { older people (the average age is mid-60s). It usually starts as a quickly growing mass in a lymph node deep inside the } \\
\text { body such as in the chest, abdomen, neck or armpit. It can also start in other areas such as the intestines, bone or even } \\
\text { the brain or spinal cord. It is slightly more common in men. Genetic tests have shown that there are different subtypes } \\
\text { of DLBCL } \\
\text { 1. Mediastinal large B cell lymphoma-It develop enlarged lymph gland and accounts about } 3 \% \text { in UK. } \\
\text { 2. Intravascular large B-cell lymphoma -In this rare subtype and found inside blood vessels, not in the lymph nodes } \\
\text { or bone marrow. }\end{array}$ \\
\hline 2. & Burkitt's lymphomas & $\begin{array}{l}\text { This is a very fast-growing lymphoma. In the Africa it often starts as a tumor of the jaw or other facial bones. It is linked } \\
\text { to infection with the Epstein-Barr virus It mostly occurs in children and young adults. They make up about } 3 \% \text { cases of } \\
\text { lymphoma in the UK and USA. It is more common in men (90\%) than women. }\end{array}$ \\
\hline 3. & $\begin{array}{l}\text { Peripheral T-cell lymphomas } \\
\qquad \text { (PTCL) }\end{array}$ & $\begin{array}{l}\text { It is a group of quickly growing NHLs that develop from mature T-cells and accounts } 6 \% \text {. These are following types and } \\
\text { have very different characteristics and behavior. } \\
\text { 1. Cutaneous T-cell lymphomas (mycosis fungoid, Sezary syndrome and others): These lymphomas start in the } \\
\text { skin and accounts } 5 \% \text {. } \\
\text { 2. Adult T-cell leukemia/lymphoma: It is caused by HTLV-1 infection. It is rare in the US and more common in the } \\
\text { Japan, Caribbean, and parts of Africa. } \\
\text { 3. Angio-immunoblastic T-cell lymphoma: It accounts only } 3 \% \text { and commonly occurs in older adults. It tends to grow } \\
\text { quickly in the lymph nodes as well as the spleen and liver. } \\
\text { 4. Extra-nodal NK/T-cell lymphoma, nasal type: It often involves the nose and upper throat but it can also invade the } \\
\text { skin and digestive tract. It is much more common in parts of Asia and South America. } \\
\text { 5. Enteropathy-associated intestinal T-cell lymphoma (EATL): EATL is a very rare type of T-cell lymphoma over } \\
\text { people } 30 \text { s and } 40 \text { s. It usually occurs in the jejunum or ileum. EATL occurs more often in people with coeliac } \\
\text { disease. It may spread to the liver, spleen, lymph nodes, gallbladder, stomach, colon and skin. } \\
\text { 6. Anaplastic large cell lymphoma (ALCL): It found in about } 2 \% \text { young peoples in their } 50 \text { s and } 60 \text { s. It usually starts } \\
\text { in lymph nodes and can also spread to skin. }\end{array}$ \\
\hline 4. & Lymphoblastic lymphoma & $\begin{array}{l}\text { It is very rare in adults and most common in children and teenagers under the age of } 35 \mathrm{~s} \text {. It usually develops from T-cells } \\
\text { but occasionally develops from B-cells. It makes up about } 2 \% \text { in the UK. It is very similar to acute lymphoblastic leukemia } \\
\text { (ALL). In lymphoma, the abnormal white blood cells (lymphocytes) are generally in the chest, Iymph nodes and thymus } \\
\text { gland. But in ALL the abnormal cells are mainly in the blood and bone marrow. . }\end{array}$ \\
\hline 5. & Blastic NK cell lymphoma & $\begin{array}{l}\text { It is a very rare type of T-cell lymphoma and can affect few adults throughout body. It tends to grow very quickly and can } \\
\text { be difficult to treat. }\end{array}$ \\
\hline 6. & $\begin{array}{l}\text { Hepatosplenic gamma delta } \\
\text { T-cell lymphoma }\end{array}$ & $\begin{array}{l}\text { It is a very rare type that starts in the liver or spleen. It tends to grow very quickly in peoples have suppressed immune } \\
\text { system due to Crohn's disease. }\end{array}$ \\
\hline 7. & $\begin{array}{l}\text { Treatment related T-cell } \\
\text { lymphomas }\end{array}$ & $\begin{array}{l}\text { It sometimes occurs after people have had an organ or stem cells or bone marrow transplant. During this people have } \\
\text { suppressed immune system resulting have high risk of developing lymphoma. }\end{array}$ \\
\hline
\end{tabular}

Table 1: Sub-types of non-Hodgkin lymphomas (NHL).

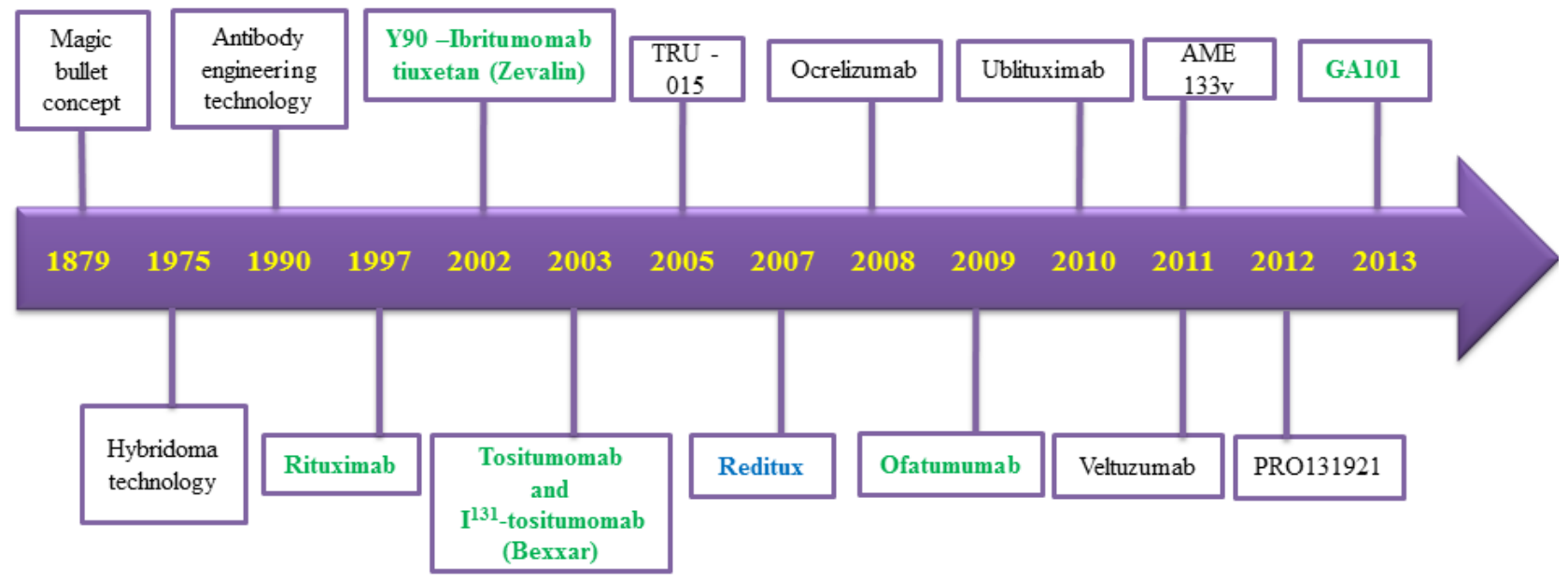

Figure 1: Schematic representation of mAbs development. This presentation is showing the evolutionary history of anti-CD20 mAbs development from 'magic bullets' concept to clinical reality against human lymphocytes. Moreover, the USA FDA approved antibodies are showing in green color whereas the India FDA approved antibody is showing in blue color.

it is not expressed in hematopoietic stem cell and differentiated B-cells. Therefore the B-cell hematopoiesis and other cell lineages are not in danger. CD20 is a non-glycosylated transmembrane phosphoprotein with four transmembrane domains. It has been a superb biomarker for immunotherapies targeting B-cell derived diseases defined by the monoclonal antibody tositumomab [11-13]. The success of rituximab prompted renewed interest in the study of a variety of clusters of differentiation (CD) molecules with the intent to use them as potential therapeutic targets. The CD20 molecules play a crucial role in cell development and survival and when modulated by antibodies result in dysregulation of vital cell survival pathways. Furthermore, it exerts various effects upon ligation with anti-CD20 mAbs and can 
Citation: Singh V, Gupta D, Almasan A (2015) Development of Novel Anti-Cd20 Monoclonal Antibodies and Modulation in Cd20 Levels on Cell Surface: Looking to Improve Immunotherapy Response. J Cancer Sci Ther 7: 347-358. doi:10.4172/1948-5956.1000373

induced several cell death mechanism such as complement-dependent cytotoxicity (CDC), antibody-dependent cellular cytotoxicity (ADCC), antibody-dependent cellular phagocytosis (ADCP) and direct induce programmed cell death (PCD). Recently, two newly characterized cell death pathways induced by anti-CD20 mAbs were reported such as lysosome mediated and reactive oxygen species mediated through NADPH [12,14-19] (Figure 2).

Learning about the limitations of rituximab and other monoclonal antibodies lead to the development of new treatments strategies, appropriate modifications in the Fc region of mAbs or development of novel anti-CD20 mAbs as well as screening and identification of small molecules which have ability to increases levels of CD20 on surface of human tumor cells. The increases in CD20 levels on cell surface and developing these novel mAbs may be increase more CD20 and antibody associations, increases their binding affinity, reducing immunogenicity and improving ADCC, CDC and PCD. In an effort to increase their cytotoxic activity $\mathrm{mAbs}$ have also been conjugated to radioisotopes, chemo-toxins and made various modifications in Fc region. The purpose of this article is to update the scientific readers those are working in the area of recent advances in the biotechnology for the development of novel anti-CD20 mAbs and identification of CD20 modulators for the improvement of immunotherapeutic responses against lymphoproliferative disorders.

\section{Development of novel anti-CD20 mAbs}

The development of anti-CD20 mAbs against lymphoma diseases were started from concept of magic bullets in 1879. The main induction of monoclonal antibodies technology or generation was initiated after the
Kohler and Milstein. His scientific work directed to a great expectation that $\mathrm{mAbs}$ would provide effective targeted therapy for cancer. Although the CD20 specific antibody B1 (renamed tositumomab) was first discovered in 1981 . However rituximab became the first $\mathrm{mAb}$ approved by the U.S. Food and Drug Administration (FDA) for use in relapsed and indolent lymphoma $[8,20]$. It is a chimeric (human-mouse) $\mathrm{mAb}$ used to treatment of $\mathrm{CD} 20$ positive B-cell malignancies; eg. non-Hodgkin lymphoma and chronic lymphocytic leukemia (CLL) and for some autoimmune diseases including rheumatoid arthritis [8,21]. Rituximab is the first generation CD20 mAb. It can induce complement-dependent cytotoxicity (CDC), antibody-dependent cellular cytotoxicity (ADCC) and direct programmed cell death as well as showed cell growth inhibition $[22,23]$. It is widely used for lymphoma therapy alone or in combination regimens mainly for relapsed and refractory lymphomas [24,25]. R-CHOP chemotherapy remains the typical regimen for recently diagnosed DLBCL [26-28]. Ibritumomab tiuxetan (Zevalin) and tositumumab (Bexxar) both are murine based mAbs also used as radio-immunotherapeutic agents against indolent NHL and follicular lymphoma (FL) patients respectively $[9,10,29]$. However, the efficacy of rituximab is modest and often variable especially when used for CLL treatment with an objective response rates ranged between $25 \%$ and $35 \%[30,31]$. Despite the unparalleled success of rituximab some patients still failed to respond or more commonly relapsed and become resistant after receiving rituximab administration.

While successes, limitations and elucidations of the mechanism of action of rituximab have increased our understanding or knowledge and helped in our goal to improve the efficacy and decreasing the

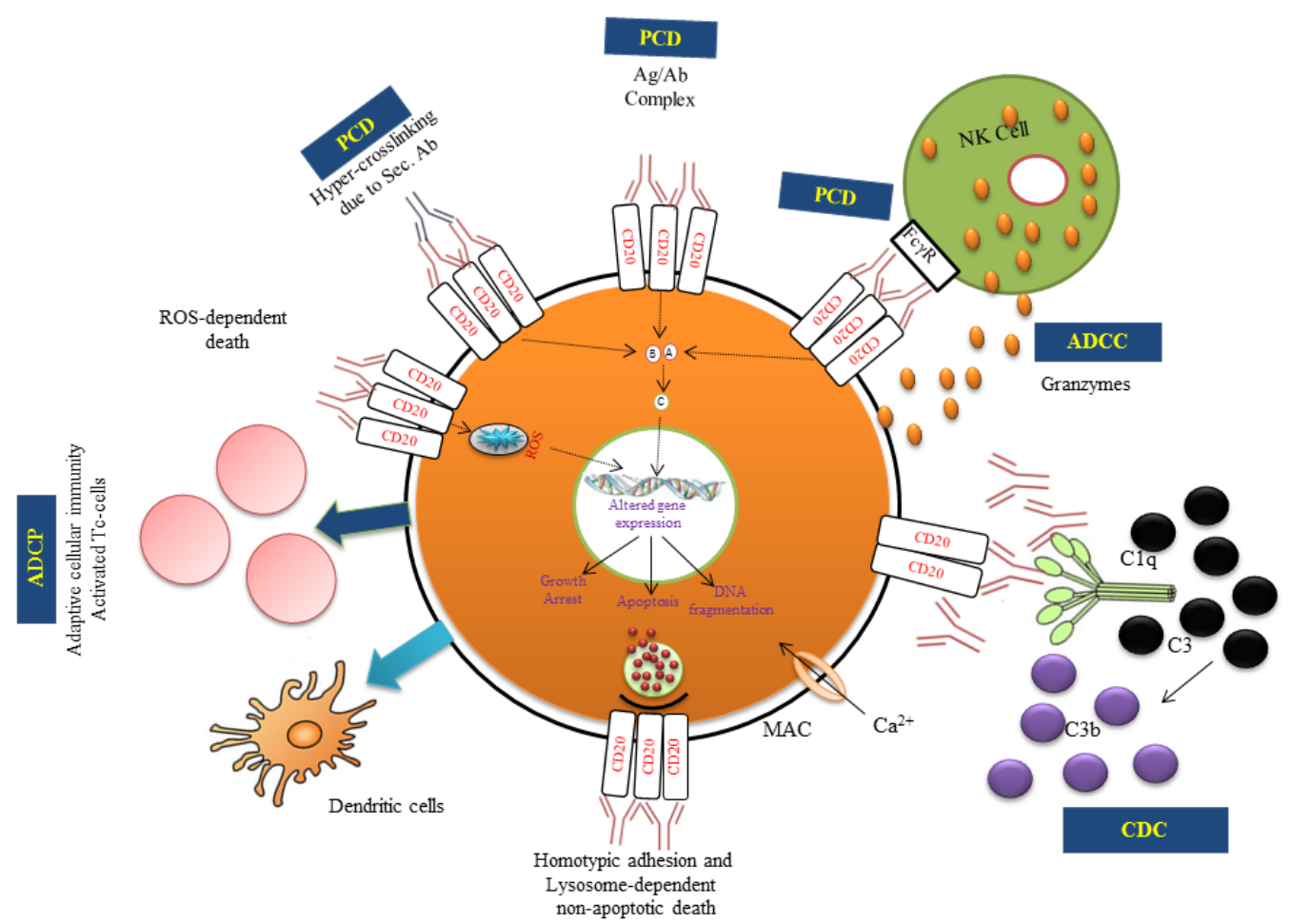

Figure 2: Identified potential effector mechanisms followed by anti-CD20 mAbs. (1) CDC - Complement dependent cytotoxicity. (2) ADCC - Antibody dependent cellular cytotoxicity. (3) PCD - Programmed cell death. (4) ADCP - Antibody dependent cellular phagocytosis. (5) ROS dependent non-apoptotic cell death. (6) Homotypic adhesion and Lysosome mediated non-apoptotic cell death. 
associated adverse effects as well as providing effective therapies for those patients who have developed resistance to rituximab. The interest in development of anti-CD20 mAbs continues to provide a major focus for scientific and clinical investigators alike and it seems to be highly probable that this research interest will continue to grow as the new generation of anti-CD20 mAbs have developed and tested clinically. Currently, there are several new generation anti-CD20 mAbs have been engineered and/or modified to improve antitumor activity and Fc binding affinity and provide advantages over rituximab that are currently undergoing clinical investigation. They may be grouped in two categories: second or third generation anti-CD20 mAb.

Second generation mAbs designed as humanized or fully human with unmodified $\mathrm{Fc}$ domain, the purpose of reducing immunogenicity compared to chimeric mAb rituximab. Second generation mAbs include Ocrelizumab, veltuzumab and ofatumumab. Ocrelizumab and veltuzumab are humanized while ofatumumab is fully human antibody. Ocrelizumab (PRO70769, 2H7) is a humanized type I anti-CD20 IgG1 $\mathrm{mAb}$. It has differences in several amino acid positions within the CDRs variable regions of the light and heavy chain as compared to rituximab. Thus it demonstrated superior binding affinity for the lowaffinity variants of the Fc $\gamma$ RIIIa receptor (CD16). Moreover it showed higher ADCC and lower CDC activity as compared to rituximab toward lymphoid malignancies. Currently, this $\mathrm{mAb}$ has been evaluated through a phase I/II study in patients with relapsed/ refractory follicular lymphoma (FL) after rituximab failed therapy and showed superior efficacy and safety $[32,33]$. Veltuzumab is another humanized type I anti-CD20 IgG1 mAb identical to rituximab with single amino acid substitution (Asp101 instead of Asn101) within the CDR3 of the variable heavy chain resulting showed reduced off-rate $[13,34]$. It also showed anti-proliferative, apoptotic and ADCC effects in vitro similar to rituximab but this modification results more potent binding avidities and a stronger effects on CDC as compared to rituximab [32,35]. In addition, the administration of very low doses either intravenous or subcutaneous routes it showed a potent anti B-cell lymphoma activity in cynomolgus monkeys (Macaca fascicularis) and reduced tumor growth in mice bearing human B-cell lymphomas [34]. Moreover, it achieves efficient delivery into the blood and pharmacologically active when administration subcutaneously compared to other routes. Of these novel mAbs, ofatumumab is at the most advance stage of clinical development with slow off-rate and high CDC activity. Ofatumumab (OFA) is a fully human type I anti-CD20 IgG1K $\mathrm{mAb}$. It recognizes an overlapping epitope on the small and big extracellular loop of CD20. Moreover, it showed better complement activation as compared to rituximab against both rituximab sensitive and resistant non-Hodgkin lymphomas cell lines expressing high levels of complement defense proteins and low levels of CD20 antigen which failed to undergo CDC with rituximab [36-42]. In addition, it showed higher potential activity than rituximab because of the high capacity for $\mathrm{C} 1 \mathrm{q}$ activation. It also showed better response against relapsed/ refractory FL and successively in a phase I/II dose escalation study with an overall response rate (ORR) of $43 \%$ [43]. Importantly, in a phase I/II studies on lymphoma and leukemia (specially on CLL) also showed increased complement activity without further increase in toxicity $[40,43]$. Possibly, the ofatumumab may be give rises to superior efficacy in combination with chemotherapy for tumor clearance and this is being investigated in ongoing trials in both FL and DLBCL.

Likewise, the third generation humanized mAbs are modified $\mathrm{mAbs}$ in the $\mathrm{Fc}$ region. The $\mathrm{Fc}$ domain was engineered with the glycol or protein. The main goal of this modification is to improving the therapeutic efficacy in all patients; particularly patients in which expression with low affinity version of the Fc receptor are found on their tumor cells.

Third generation anti-CD20 mAbs include AME133v, Pro131921 (v114), GA101, R603/EMAB-6 and TRU-015.They are ongoing in early phases of clinical development. AME-133v (LY2469298, ocaratuzumab) is an Fc protein engineered humanized type I IgG1 $\mathrm{mAb}$ which currently being evaluated in a Phase I/II dose escalation study in patients with relapsed/refractory follicular B-cell NHL [44]. In vitro study suggested that it has 13 to 20 fold more binding affinity with CD20 and 5-7 fold higher avidity to the low affinity (F/F and F/V) variants of Fc $\gamma$ RIIIa receptor thereby improving killing of B-cell NHL $\sim 10$ fold as compared to rituximab [44-46]. Although, the clinical trial with AME-133v are currently ongoing and it will need to be compared to rituximab in randomized clinical trials to substantiate its potential clinical advantages. Pro131921 (v114) is derived from 2H7. It is another humanized IgG1 Fc protein engineered antibody and displays 30 -fold more binding affinity to the low variant of Fc $\gamma \mathrm{R}$ (RIIIa: FF or FV) over rituximab [47-49]. In vitro study revealed that it has higher binding affinity showed improved ADCC activity about 10 fold more as compared to rituximab. Although, preclinical studies in non-human primates (cynomolgus monkeys; Macaca fascicularis) revealed that treatment with Pro13192 is associated in a dose-dependent reversible neutropenia and thrombocytopenia [49]. However, Phase I/II clinical studies demonstrated better anti-tumor efficacy in patients with relapsed and /or refractory indolent lymphoma who failed rituximab containing regimens [50]. But, clinical development has been recently terminated due to assess safety of escalating doses of Pro13192 in patients with NHL and CLL. LFB-R603/EMAB-6 (Ublituximab, LFP) is another chimeric glyco-engineered IgG1 $\mathrm{mAb}$ showed enhanced Fc $\gamma$ RIII affinity. It was raised in rat cell lines YB2/0 using EMABLING technology thus resulting in naturally low fucose contents in its $\mathrm{FC}$ region [51]. LFB-R603/EMAB-6 has similar CDC and PCD activities whereas ADCC response rate found about $35 \%$ higher at $50 \mathrm{ng} / \mathrm{ml}$ while rituximab induced less than $5 \%$ at the same concentration in low CD20 expressing CLL cells [51]. Furthermore, preclinical studies also revealed that it can disrupt NF- $\mathrm{kB} /$ Snail/RKIP/PTEN/AKT signaling in B-cell NHL cell lines that are resistant to chemotherapy and immunochemotherapy [52]. It is currently in a Phase I/II clinical study in CLL. In contrast to the other anti-CD20 mAbs GA101 (RO5072759, obinutuzumab) also known as the gazyva is the first fully humanized type II IgG1 mAb which have glycol-engineered Fc domain with nonfucosylated oligosaccharides to enhance the interaction with $\mathrm{Fc}_{\mathrm{c}} \mathrm{Rs}$ particularly Fc $\gamma$ RIIIa (CD16) therefore showed enhancing ADCC activity compared to other anti-CD20 mAbs [53-56]. Recently (in November 2013) it has FDA approved $\mathrm{mAb}$ for use in combination with chlorambucil to treat patients with previously untreated chronic lymphocytic leukemia (CLL). Preclinical studies suggested that the modified Fc region of GA101 improved about 50 fold binding affinity to FcyRIII and 10 to 100 fold increased cell death through ADCC mechanism against CD20 positive NHL cell lines [57-60]. Moreover, in vitro study also demonstrated that modification in elbow hinge regions promotes direct programmed cell death mechanism in several NHL cell lines and primary malignant B-cells $[12,49]$. However, these modifications result in reduced CDC activity [61]. GA101 has also showed superior therapeutic efficacy in subcutaneous lymphoma xenograft models of diffuse large B-cell lymphoma and mantle cell lymphoma when used as monotherapy or in combination with cyclophosphamide [62-65]. As compared to rituximab GA101 showed significantly superior B-cell depletion not only in peripheral blood but also in spleen and lymph nodes in non-human primates and hCD20 
transgenic mice [61,63,64,66-68]. GA101 demonstrated a favorable safety profile with no dose-limiting toxicities during phase I/II study in patients with relapsed/refractory CD20 positive cells including CLL, DLBCL and other NHLs [69]. Moreover, the pharmacokinetics of GA101 is mostly comparable to those of rituximab and dosedependent. However, the significant inter and intra-patient variabilities have been observed. Therefore, the clinical relevance further will need to be investigation. TRU-015 ((CytoxB20G) is a single chain antiCD20 molecule that is a small modular immuno-pharmaceutical drug composed of human IgG1 $\mathrm{Fc}$ and $\mathrm{CH} 2$ and $\mathrm{CH} 3$ hinge regions which linked directly to an anti-CD20 specific Fv regions [70-72]. It has high ADCC and low CDC activating potential. It is currently in Phase II clinical development for inflammatory disease is ongoing particularly against rheumatoid arthritis $[73,74]$.

\section{Modulation in CD20 Surface Levels}

A number of CD20 mAbs are now used in clinical practice or are in different stages of development (Table 3). Most of them such as rituximab, 90Y-Ibritumomab, tositumomab, ofatumumab and Obinutuzumab (GA 101) have been FDA approved for use in NHLs and RA. All anti-CD20 mAbs are biochemically and functionally divided into two distinct subtypes such as rituximab-like type I and tositumomab-like type II as shown in Table 2 [75,76].

In clinical applications, the efficacy of anti-CD20 mAbs seems to be decline after a period of months of treatments due to therapeutic resistance. Actually the explanation for this therapeutic resistance is not clear. The possible mechanisms of this resistance of B-cell NHLs against anti-CD20 mAbs therapy may be include three patterns: (I) Protection of the tumor cells from mAbs mediated depletion of B-cell lymphoma by ADCC, CDC and apoptotic stimulation (II) Inadequate binding of mAbs to the CD20 molecule and (III) Low levels of CD20 antigens on cells surface or reduce CD20 surface levels on cells.

Although, some investigators provide information that decreased levels of CD20 expression and/ or harbor low levels of CD20 on surface of malignant B-cells may be one of the major contributing factors for antibody response $[103,104]$. However, there is general agreement that diseases such as chronic lymphocytic leukemia display the CD20 cell surface molecules in fairly low levels and respond proportionally less as compared to others low grade B-cell malignancies [30,104-106]. Some studies are strongly suggested that cytokines, some inhibitors and radiation exposure showed strong ability to significantly induced expression of CD20, HER2 and EFGR at both total protein levels as well as availability on cell surface specifically in malignant cells, not on normal cell lineages. In relation to CD20 expression some reports provide strong evident that bryostatin-1, interleukin-4, granulocyte macrophage colony stimulating factor, tumor necrosis factor- $\alpha$, interferon- $\alpha$ and $\gamma$ radiation have strong ability to induce changes in CD20 expression at transcription, translation and epigenetically as well as their associated transcription factors as showing in Table 4 [107-113].

\begin{tabular}{|c|c|c|}
\hline Function & Type I & Type II \\
\hline $\begin{array}{c}\text { Modulation of CD20 antigen Redistribute } \\
\text { CD20 to lipid rafts }\end{array}$ & Yes & No \\
\hline CDC & High & Minimal \\
\hline ADCC & High & High \\
\hline Homotypic adhesion & Weak & Strong \\
\hline Apoptosis induction & $\begin{array}{c}\text { Caspase } \\
\text { dependent }\end{array}$ & $\begin{array}{l}\text { Caspase independent } \\
\text { Lysosome mediated }\end{array}$ \\
\hline
\end{tabular}

Table 2: Following are general differences between type I and type II anti-CD20 mAbs.
The bryostatin-1 induced increases in CD20 expression were found at the transcriptional level. The effects of bryostatin-1 on CD20 expression in NHL derived cells was apparently mediated through the MAPK/ERK signal transduction pathway and involved protein kinase $C$ [111]. An increase in CD20 transcription was also shown to be triggered by CpG independently of PU.1 transcription factor in CLL cells [128]. Recently, it was also showed that L-744,832 induced inhibition of farnesyltransferase activity leads to up-regulation of CD20 levels and to improved human tumor cell killing activity followed by anti-CD20 mAbs. Moreover, the inhibition of farnesyltransferase activity was found to be associated with increased binding affinity of PU.1 and Oct-2 to the CD20 promoter sequences [117]. Bortezomib a proteasome inhibitor have potential to induced expression of $\mathrm{COOH}$ terminal region of the internal domain of $\mathrm{CD} 20$ but not the whole CD20 molecule [118]. Recent study addressed the potential activity of bortezomib in more detail that the unexpected negative influence of proteasome inhibitors on the $\mathrm{CD} 20$ levels as well as rituximab mediated CDC and ADCC toward CD20 positive B-cell malignancies [119]. The CD20 expression is also regulated by epigenetic mechanisms. For example 5-azacytidine (inhibitor of DNA methyltransferase activity) can significantly increases the CD20 expression in B-cell lymphoma [120] and trichostatin-A (a modulator of histone-acetylation status) also have ability to increases CD20 mRNA and protein levels in RRBL1 cells, a B-cell lymphoma cell line $[121,122]$. Two other HDAC inhibitors such as valproic acid (VPA) and romidepsin both have ability to increased CD20 expression at protein and mRNA levels in B-cell lymphoma cell lines. The VPA-mediated increase in CD20 expression is clinically achievable and safe, but insufficient for inducing cell death. Moreover, it is also revealed that HDAC inhibitors trans-activated the CD20 gene promoter through hyper-acetylation and Sp1 recruitment [123]. Whereas, other reports are exploited that CD20 antigens is down-regulated by anti-CD20 mAb rituximab treatment. It is a wellrecognized phenomenon in patients with non-Hodgkin's lymphomas particular in chronic lymphocytic leukemia (CLL). In CLL, rituximab mediated down modulation of CD20 is associated with reduced levels of CD20 mRNA at in vitro and in vivo indicating regulation of CD20 expression at the level of transcription $[129,130]$. Recently it is also reported that initially CD20 antigens disappeared in patients with CLL treated with rituximab containing salvage regimens occurred in 4 out of $8(50 \%)$ tested patients after some time CD20 levels returned at progression or recovered. Half of whom developed Richter's syndrome [131]. One more report indicated that lenalidomide or CD40 ligation in normal B-cells down regulates CD20 levels [132,133]. Radiation induced changes in CD20 expression on B-cell lymphoma were identified first time in 1997 by Philippe et al. [131]. Later on, Kunala et al. was also suggested that exposure of ionizing radiation (10Gy) can significantly increases CD20 surface expression in a dose and time dependent manner in IM9, IM9/Bcl-2 and Ramos neoplastic B-cell lines. In contrast, he was also investigated that CD20 expression was not induced in CD20-negative Molt- 4 cell line whereas it was increases only about $25 \%$ in the GM1310B normal B-cell line. Moreover, the overexpression of $\mathrm{Bcl}-2$ protein does not inhibited radiation induced CD20 expression. In addition, the treatment of cells with actinomycin-D is known to inhibit RNA synthesis followed by $10 \mathrm{~Gy} \gamma$-radiation. This suggests a transcriptional regulation of CD20 expression rather than a simple alteration in cell surface morphology or surface level of CD20 on the targets cells $[126,127]$. Gupta et al. strongly suggested that the significant increases in cell surface expression of CD20 were transient and cell type dependent manner in logarithmically growing Daudi and Raji cells followed by 0.5 and/or $1.5 \mathrm{~Gy}$ radiation exposure. The enhanced expression of $\mathrm{CD} 20$ antigen was associated with 
Citation: Singh V, Gupta D, Almasan A (2015) Development of Novel Anti-Cd20 Monoclonal Antibodies and Modulation in Cd20 Levels on Cell Surface: Looking to Improve Immunotherapy Response. J Cancer Sci Ther 7: 347-358. doi:10.4172/1948-5956.1000373

\begin{tabular}{|c|c|c|c|c|c|}
\hline CD20 mAbs & MFC/ Type & Source & $\begin{array}{c}\text { Regimen } \\
\left(\text { dose } \mathrm{mg} / \mathrm{m}^{2}\right)\end{array}$ & $\begin{array}{l}\text { Mechanism of } \\
\text { action }\end{array}$ & 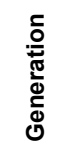 \\
\hline $\begin{array}{l}\text { Rituximab } \\
\text { (Rituxan, MabThera } \\
\quad \text { and Zytux) } \\
\text { Approved in US } 1997\end{array}$ & $\begin{array}{l}\text { Biogen, Idec and } \\
\text { Genentech } \\
\text { Type I } \\
\text { mAb }\end{array}$ & Chimeric & $\begin{array}{l}\text { Rituximab (166 patients with Refractory/ relapsed FL, ORR 48\%) } \\
\text { [8,77,78] } \\
\text { R-GMCSF (49 Patients with relapsed FL, ORR 74\% [79] } \\
\text { R-bendamustine (33 patients with Relapsed FL or MCL, ORR 70\%) } \\
\text { [80,81] } \\
\text { R-CHOP (63 Untreated patients of DLBCL, ORR 90\% ) [82] }\end{array}$ & $\begin{array}{l}\text { CDC, ADCC, PCD, } \\
\text { ADCP }\end{array}$ & \multirow{4}{*}{$\stackrel{+\infty}{\stackrel{\omega}{*}}$} \\
\hline $\begin{array}{c}\mathrm{Y}^{90} \text {-lbritumomab } \\
\text { tiuxetan (Zevalin) } \\
\text { Approved in US } 2002\end{array}$ & $\begin{array}{l}\text { Biogen IDEC } \\
\text { Pharmaceuticals Corp } \\
\text { Type I } \\
\text { mAb }\end{array}$ & Murine $\lg \mathrm{G} 1 \mathrm{~K}$ & $\begin{array}{l}\text { Zevalin (54 patients of Rituximab refractory FL, ORR } 74 \% \text { ) }[83,84] \\
\text { Zevalin vs Rituximab, randomized multicenter study }(143 \text { patients of } \\
\text { Relapsed or refractory FL, ORR } 80 \text { vs } 56 \% \text { ) }[84,85]\end{array}$ & $\begin{array}{l}\text { High CDC } \\
\text { Low ADCC }\end{array}$ & \\
\hline $\begin{array}{l}\text { Tositumomab (B1) } \\
\text { and I I11-Tositumomab } \\
\quad \text { (Bexxar) } \\
\text { Approved in US } 2003\end{array}$ & $\begin{array}{l}\text { Corixa, Glaxo } \\
\text { Smithkline } \\
\text { Type II } \\
\text { mAb }\end{array}$ & Murine $\lg G 2 a \lambda$ & $\begin{array}{l}\text { Bexxar ( } 250 \text { patients of Relapsed/refractory indolent } \mathrm{FL} \text { and } \\
\text { transformed NHL, ORR } 47 \%-68 \% \text { repectively) [86] } \\
\text { Bexxar ( } 76 \text { patients of Stage III or IV FL, ORR } 95 \%) \text { [87] } \\
\text { Bexxar +Fludarabine ( } 35 \text { patients of Early stage FL, ORR } 98 \% \text { ) [88] } \\
\text { Bexxar vs tositumomab (78 patients of Relapsed or refractory NHL, } \\
\text { ORR } 55 \% \text { vs 19\%) [89-91] }\end{array}$ & $\begin{array}{l}\text { High PCD } \\
\text { Low CDC }\end{array}$ & \\
\hline $\begin{array}{l}\text { Reditux } \\
\text { Approved in India } \\
2007\end{array}$ & $\begin{array}{l}\text { Dr. Reddy Laboratories } \\
\text { Type I } \\
\text { mAb }\end{array}$ & Murine $\lg G 1$ & Reditux (72 patients of DLBCL, CR 82\%) [92] & Biosimilar & \\
\hline $\begin{array}{l}\text { Ocrelizumab } \\
(2 \mathrm{H} 7 ; \text { PRO70769) } \\
\quad \text { Phase III }\end{array}$ & $\begin{array}{l}\text { Genentech /Roche/ } \\
\text { Biogen } \\
\text { Type I } \\
\text { mAb }\end{array}$ & Humanized lgG1 & $\begin{array}{l}\text { Ocrelizumab (47 patients of Relapsed/Refractory FL, ORR 38\%) } \\
750 \text { [33] }\end{array}$ & $\begin{array}{l}\text { High ADCC } \\
\text { Low CDC }\end{array}$ & \multirow{3}{*}{ 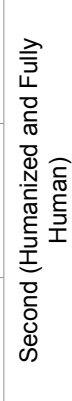 } \\
\hline $\begin{array}{l}\text { Veltuzumab (IMMU- } \\
\text { 106; hA20) } \\
\text { Phase II }\end{array}$ & $\begin{array}{l}\text { Immunomedics USA } \\
\text { Type I } \\
\text { mAb }\end{array}$ & Humanized lgG1k & $\begin{array}{l}\text { Veltuzumab (82 patients of Relapsed/refractory B-cell NHL) 80-750 } \\
\text { [32] } \\
44 \% \text { ORR in FL } \\
83 \% \text { ORR in MZL } \\
43 \% \text { ORR in DLBL }\end{array}$ & High CDC & \\
\hline $\begin{array}{l}\text { Ofatumumab } \\
(2 F 2 ; \text { HuMax-CD20; } \\
\text { Arzerra) } \\
\text { Approved in US } 2009\end{array}$ & $\begin{array}{l}\text { Genmab, } \\
\text { Glaxosmithkline } \\
\text { Typr I } \\
\text { mAb }\end{array}$ & Fully Human IgG1k & $\begin{array}{l}\text { OFA, } 500-1000 \text { (116 patients of Refractory FL, ORR } 13-10 \%) \text { [93] } \\
\text { OFA-CHOP, } 500-1000 \text { ( } 59 \text { patients of Untreated FL, } 90-100 \%) \text { [94] } \\
\text { OFA-FC, } 500-1000 \text { ( } 61 \text { patients of Frontline therapy for CLL, } 77- \\
73 \% \text { ) [95] }\end{array}$ & High CDC & \\
\hline $\begin{array}{l}\text { Ocaratuzumab } \\
\text { (AME-D, AME-133) } \\
\text { Phase II }\end{array}$ & $\begin{array}{l}\text { Mentrik Biotech, } \\
\text { Applied molecular } \\
\text { evolution } \\
\text { Type I } \\
\text { mAb }\end{array}$ & $\begin{array}{l}\text { Humanized } \\
\text { IgG1(Engineered Fc } \\
\text { portion) }\end{array}$ & $\begin{array}{l}\text { Ocaratuzumab, } 100-375 \text { (56 patients of Relapsed/Refractory FL, } \\
\text { ORR } 36 \% \text { ) [96] } \\
\text { Ocaratuzumab, } 375 \text { (50 patients of Relapsed/Refractory FL with low- } \\
\text { affinity genotype of FcyRIIIa, ORR } 30 \% \text { ) [97] }\end{array}$ & High ADCC & \multirow{5}{*}{ 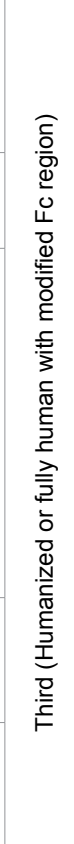 } \\
\hline $\begin{array}{l}\text { PRO131921 } \\
\text { (RhuMAb; v114) } \\
\text { Phase I/II }\end{array}$ & $\begin{array}{c}\text { Genentech } \\
\text { Type I } \\
\text { mAb }\end{array}$ & $\begin{array}{c}\text { Humanized } \\
\text { IgG1(Engineered Fc } \\
\text { portion) }\end{array}$ & $\begin{array}{l}\text { PRO131921, 25-800 (24 patients of Relapsed/refractory B cell NHL, } \\
\text { ORR 27\%) [98] }\end{array}$ & $\begin{array}{l}\text { High CDC } \\
\text { Low ADCC }\end{array}$ & \\
\hline $\begin{array}{c}\text { Obinutuzumab } \\
\text { (GA101;Gazyva) } \\
\text { Approved in US Nov } \\
2013\end{array}$ & $\begin{array}{l}\text { Roche } \\
\text { Type II } \\
\text { mAb }\end{array}$ & $\begin{array}{l}\text { Humanized IgG2K } \\
\text { (Glycoengineered Fc } \\
\text { portion) }\end{array}$ & $\begin{array}{l}\text { GA101, } 1600 / 800-400 / 400 \text { (29 patients of Refractory B-cell NHL, } \\
\text { ORR } 60-35 \% \text { ) [99] } \\
\text { G-CHOP, } 1600 / 800-400 / 400 \text { (28 patients of Relapsed or refractory } \\
\text { FL, ORR } 94 \% \text { ) } \\
\text { [100,101] } \\
\text { G-FC, } 1600 / 800-400 / 400 \text { (28 patients of Relapsed or refractory FL, } \\
\text { ORR } 93 \% \text { ) [100] }\end{array}$ & $\begin{array}{l}\text { High PCD \& } \\
\text { ADCC, } \\
\text { Low CDC }\end{array}$ & \\
\hline $\begin{array}{c}\text { Ublituximab } \\
\text { (LFB-R603, EMAB-6) } \\
\text { Phase I }\end{array}$ & $\begin{array}{c}\text { GTC Bio therapeutics, } \\
\text { LFB Biotechnologies } \\
\text { Type I } \\
\text { mAb }\end{array}$ & $\begin{array}{l}\text { Chimeric; IgG1 } \\
\text { Glycoengineered }\end{array}$ & Ublituximab, (12 patients of Advanced CLL, ORR 35\%) [102] & High ADCC & \\
\hline $\begin{array}{l}\text { TRU-015 } \\
\text { Phase II }\end{array}$ & $\begin{array}{c}\text { Trubion } \\
\text { Pharmaceuticals Inc., } \\
\text { Wyeth } \\
\text { Single chain protein }\end{array}$ & SMIL & 37 patients of RA patients [74] & $\begin{array}{l}\text { High ADCC } \\
\text { Low CDC }\end{array}$ & \\
\hline
\end{tabular}

Table 3: List of anti-CD20 monoclonal antibodies.

transcriptional up-regulation of CD20 mRNA and CD20 regulatory transcription factors. Moreover, the changes in CD20 surface levels were found to be correlated with overall changes in oxidative stress and mitochondrial membrane potential [112]. Recently, Singh et al. demonstrated that sub-lethal dose (0.5Gy) of $\gamma$-radiation can induce $\sim 3$ fold CD20 levels on Burkitt's lymphoma cell line 'Daudi' and it was also associated with changes in oxidative condition in intracellular milieu $[124,125]$. Moreover, cytokines which involved in CD20 expression also cause robust intracellular oxidative bursts. Accumulating evidence indicates that CD20 expression in malignant cells can be modulated 
Citation: Singh V, Gupta D, Almasan A (2015) Development of Novel Anti-Cd20 Monoclonal Antibodies and Modulation in Cd20 Levels on Cell Surface: Looking to Improve Immunotherapy Response. J Cancer Sci Ther 7: 347-358. doi:10.4172/1948-5956.1000373

\begin{tabular}{|c|c|c|}
\hline Compound/ Reagents Name & Regulatory mechanism & References \\
\hline Bryostatin-1 & $\begin{array}{l}\text { It is immune modulator have ability to enhanced expression of CD20 at both mRNA and protein levels in human tumor B-cells. } \\
\text { Moreover, the enhanced expression of CD20 was dependent of phosphorylation of MAPK kinase/ERK signal transduction } \\
\text { pathway in association with protein kinase C, but was independent of p38 MAPK and insensitive to dexamethasone. }\end{array}$ & [111] \\
\hline Interleukin-4 & $\begin{array}{l}\text { Interleukin-4 (IL-4) has ability to increased CD20 promoter activity and CD20 expression but modestly improved rituximab } \\
\text { activity in RRCL and in primary B-cell lymphoma cells suggesting the existence of a defect in CD20 protein transport in } \\
\text { RRCL. }\end{array}$ & [106] \\
\hline GMCSF & $\begin{array}{l}\text { Granulocyte-macrophage colony stimulating factor (GM-CSF) has been shown to enhance CD20 antigen expression, } \\
\text { augment antibody-dependent cell-mediated cytotoxicity, and stimulate immune cell proliferation. This may lead to an } \\
\text { improved anti-tumor effect of rituximab while reducing the severity of chemotherapy-induced myelosuppression }\end{array}$ & [114] \\
\hline Tumor necrosis factor- $\alpha$ & TNF- $\alpha$ showed enhanced CD20 expression on cells from patients with B-CLL in vitro. & [108] \\
\hline Statins & $\begin{array}{l}\text { Statins are inhibitors of cholesterol synthesis and decreases the production of prenyltransferase groups (farnesyl and } \\
\text { geranylgeranyl pyrophosphates) have ability to induce conformational changes in CD20 molecules and impair rituximab } \\
\text { mediated complement dependent cytotoxicity }\end{array}$ & [115] \\
\hline Interferon- $\alpha$ & Interferon- $\alpha$ has ability to directly upregulating CD20 levels and priming may augment the effectiveness of antibody therapy. & [116] \\
\hline L-744,832 & $\begin{array}{l}\text { L-744,832 is most potent inhibitor of farnesyltransferase and has ability to up-regulation of CD20 levels and improved } \\
\text { antitumor activity of anti-CD20 mAbs. Moreover, it induced binding of PU.1 and Oct- } 2 \text { with the CD20 promoter sequences }\end{array}$ & [117] \\
\hline Bortezomib & $\begin{array}{l}\text { Bortezomib is a proteasome inhibitor has ability to induced expression of } \mathrm{COOH} \text {-terminal region but not the whole CD20 } \\
\text { molecule. One more report revealed that prolonged ( } 48 \text { hours) incubation with bortezomib lead to a significant decrease } \\
\text { in levels of CD20 on cell surface as well as R-CDC. Moreover, these effects may be partly reversed by bafilomycin A1, an } \\
\text { inhibitor of lysosomal/autophagosomal pathway of protein degradation. }\end{array}$ & {$[118,119]$} \\
\hline 5-azacytidine & $\begin{array}{l}\text { 5-azacytidine is inhibitor of DNA methyltransferase has ability to induced changes CD20 expression in primary B-cell } \\
\text { lymphoma cells }\end{array}$ & [120] \\
\hline Trichostatin-A & $\begin{array}{l}\text { It is an inhibitor of the class I and II mammalian histone deacetylase (HDAC) families of enzymes. It has potential to regulate } \\
\text { of both CD20 mRNA and protein levels by epigenetically in B-cell lymphoma. }\end{array}$ & {$[121,122]$} \\
\hline $\begin{array}{l}\text { Valproic acid (VPA) and } \\
\text { Romidepsin }\end{array}$ & $\begin{array}{l}\text { Valproic acid (VPA) and romidepsin are HDAC inhibitors have ability to increased CD20 expression mediated through } \\
\text { hyper-acetylation and recruitment of Sp1 }\end{array}$ & [123] \\
\hline Radiation-induced & $\begin{array}{l}\text { Cells exposed to radiation, CD20 expression were found to be significantly higher at mRNA and protein levels in B-cell } \\
\text { lymphoma. The levels of CD20 on cell surface associated with generation of free radicals and changes oxidative stress in } \\
\text { cellular milieu and associated in changes Oct 1, Oct } 2 \text {, PU.1, and Bob } 1 \text {. Moreover, it was found that the overexpression of } \\
\text { Bcl-2 is not inhibiting CD20 expression. }\end{array}$ & $\begin{array}{l}{[112,124-} \\
127]\end{array}$ \\
\hline
\end{tabular}

Table 4: List of CD20 modulatory compounds and/or reagents.

at transcriptional, transcriptional, posttranscriptional and even posttranslational levels and their occurrence and significance may be vary depending on the type of malignancies. However, the precise mechanisms of changes in CD20 expression still unclear and further need to be investigation.

\section{Conclusion}

In conclusion over the last 10 years rituximab is used against the treatment of all common B-cell malignancies. Based on this success, limitations and elucidation of the mechanism various novel anti$\mathrm{CD} 20 \mathrm{mAbs}$ has been developed to improved clinical outcomes with outstanding performance in ADCC, CDC and PCD and reduced immunogenicity. Although, the mechanisms of action of each antiCD20 mAbs has been well studied in preclinical settings. However, the variability seen in clinical responses of these mAbs may be depend on level of CD20 expression, levels of circulating soluble CD20, presence of effector cells, CD20 binding epitope and kinetics, binding with Fc receptors, tissue distribution and tumor burden. Singh et al. recently published a report provide information that sub-lethal dose of radiation can induced CD20 surface levels on cells determined efficacy of both type I (rituximab) and type II (tositumomab) anti-CD20 mAbs in vitro. However, more preclinical and clinical investigations need to be confirmed. Therefore, the ability to selectively control CD20 expression and appropriate modifications in $\mathrm{Fc}$ domain of mAbs may be great importance in enhancing therapeutic values and in optimizing antiCD20 immunotherapy and radio-immunotherapy. The modulation in CD20 expression may provide more binding sites for anti-CD20 $\mathrm{mAbs}$ and may play a major role in therapeutic response. Based on this information and previous data we suggested that use of external beam radiotherapy (in a site selective manner) just prior to immunotherapy may be beneficial for tumor clearance and maximum clinical outcomes.

\section{Acknowledgements}

The work was supported by $\mathrm{NIH}$ with the grant no. $\mathrm{NCl}(\mathrm{NIH}) \mathrm{RO} 1 \mathrm{CA} 184137$ and the authors are grateful to University Grant Commission for the grant award (to VS) and very thankful to the Director of INMAS for providing scientific infrastructure to carry out our research work and prepare this manuscript.

\section{References}

1. Ferlay J, Soerjomataram I, Dikshit R, Eser S, Mathers C, et al. (2015) Cancer incidence and mortality worldwide: sources, methods and major patterns in GLOBOCAN 2012. International journal of cancer 136: E359-386.

2. Global Burden of Disease Cancer Collaboration, Fitzmaurice $C$, Dicker D, Pain A, Hamavid H, et al. (2015) The Global Burden of Cancer 2013. JAMA Oncol 1: $505-527$.

3. Hainsworth JD (2000) Monoclonal antibody therapy in lymphoid malignancies. Oncologist 5: 376-384.

4. (1990) A randomized clinical trial of chlorambucil versus COP in stage B chronic lymphocytic leukemia. The French Cooperative Group on Chronic Lymphocytic Leukemia. Blood 75: 1422-1425.

5. Sledge GW Jr (2005) What is targeted therapy? J Clin Oncol 23: 1614-1615

6. Strebhardt K, Ullrich A (2008) Paul Ehrlich's magic bullet concept: 100 years of progress. Nat Rev Cancer 8: 473-480.

7. Kohler G, Milstein C (1975) Continuous cultures of fused cells secreting antibody of predefined specificity. Nature 256: 495-497.

8. McLaughlin P, Grillo Lopez AJ, Link BK, Levy R, Czuczman MS, et al. (1998) Rituximab chimeric anti-CD20 monoclonal antibody therapy for relapsed indolent lymphoma: half of patients respond to a four-dose treatment program $\mathrm{J}$ Clin Oncol 16: 2825-2833.

9. Kaminski MS, Zelenetz AD, Press OW, Saleh M, Leonard J, et al. (2001) Pivotal study of iodine I 13 tositumomab for chemotherapy-refractory low-grade or transformed low-grade B-cell non-Hodgkin's lymphomas. J Clin Oncol 19: 3918-3928.

10. Horning SJ, Younes A, Jain V, Kroll S, Lucas J, et al. (2005) Efficacy and safety of tositumomab and iodine-13 tositumomab (Bexxar) in B-cell lymphoma, progressive after rituximab. J Clin Oncol 23: 712-719. 
Citation: Singh V, Gupta D, Almasan A (2015) Development of Novel Anti-Cd20 Monoclonal Antibodies and Modulation in Cd20 Levels on Cell Surface: Looking to Improve Immunotherapy Response. J Cancer Sci Ther 7: 347-358. doi:10.4172/1948-5956.1000373

11. Alduaij W, Illidge TM (2011) The future of anti-CD20 monoclonal antibodies: are we making progress? Blood 117: 2993-3001.

12. Alduaij W, Ivanov A, Honeychurch J, Cheadle EJ, Potluri S, et al. (2011) Novel type II anti-CD20 monoclonal antibody (GA101) evokes homotypic adhesion and actin-dependent, lysosome-mediated cell death in B-cell malignancies. Blood 117: 4519-4529.

13. Goldenberg DM, Morschhauser F, Wegener WA(2010) Veltuzumab (humanized anti-CD20 monoclonal antibody): characterization, current clinical results, and future prospects. Leuk Lymphoma 51: 747-755.

14. Ren H, Zhang C, Su L, Bi X, Wang C, et al. (2015) Type II anti-CD20 mAbinduced lysosome mediated cell death is mediated through a ceramidedependent pathway. Biochem Biophys Res Commun 457: 572-577.

15. Honeychurch J, Alduaij W, Azizyan M, Cheadle EJ, Pelicano H, et al. (2012) Antibody-induced nonapoptotic cell death in human lymphoma and leukemia cells is mediated through a novel reactive oxygen species-dependent pathway Blood: 3523-3533.

16. Cragg MS, Morgan SM, Chan HT, Morgan BP, Filatov AV, et al. (2003) Complement-mediated lysis by anti-CD20 mAb correlates with segregation into lipid rafts. Blood 101: 1045-1052.

17. Beers SA, French RR, Chan HT, Lim SH, Jarrett TC, et al. (2010) Antigenic modulation limits the efficacy of anti-CD20 antibodies: implications for antibody selection. Blood 115: 5191-5201.

18. Lim SH, Beers SA, French RR, Johnson PW, Glennie MJ, et al. (2010) AntiCD20 monoclonal antibodies: historical and future perspectives. Haematologica 95: $135-143$

19. Mattes MJ, Michel RB, Goldenberg DM, Sharkey RM (2009) Induction of apoptosis by cross-linking antibodies bound to human B-lymphoma cells: expression of Annexin $\mathrm{V}$ binding sites on the antibody cap. Cancer Biother Radiopharm 24: 185-193.

20. Nadler LM, Ritz J, Hardy R, Pesando JM, Schlossman SF, et al. (1981) A unique cell surface antigen identifying lymphoid malignancies of $B$ cell origin. $J$ Clin Invest 67: 134-140.

21. Edwards JC, Cambridge G (2006) B-cell targeting in rheumatoid arthritis and other autoimmune diseases. Nat Rev Immunol 6: 394-403.

22. Robak T, Robak E (2011) New anti-CD20 monoclonal antibodies for the treatment of B-cell lymphoid malignancies. BioDrugs 25: 13-25.

23. Jaglowski SM, Alinari L, Lapalombella R, Muthusamy N, Byrd JC (2010) The clinical application of monoclonal antibodies in chronic lymphocytic leukemia. Blood 116: 3705-3714.

24. Coiffier B (2007) Rituximab therapy in malignant lymphoma. Oncogene 26 3603-3613.

25. Czuczman MS, Gregory SA (2010) The future of CD20 monoclonal antibody therapy in B-cell malignancies. Leuk Lymphoma 51: 983-994.

26. Coiffier B (2006) Rituximab and CHOP-like chemotherapy in good-prognosis diffuse large-B-cell lymphoma. Nat Clin Pract Oncol 3: 594-595.

27. Pfreundschuh $M$, Trumper L, Osterborg A, Pettengell R, Trneny $M$, et al (2006) MabThera International Trial, CHOP-like chemotherapy plus rituximab versus $\mathrm{CHOP}$-like chemotherapy alone in young patients with good-prognosis diffuse large-B-cell lymphoma: a randomised controlled trial by the MabThera International Trial (MInT) Group. The Lancet. Oncology 7: 379-391.

28. Coiffier B, Lepage E, Briere J, Herbrecht R, Tilly H, et al. (2002) CHOP chemotherapy plus rituximab compared with $\mathrm{CHOP}$ alone in elderly patients with diffuse large-B-cell lymphoma. N Engl J Med 346: 235-242.

29. Gordon LI, Molina A, Witzig T, Emmanouilides C, Raubtischek A, et al. (2004) Durable responses after ibritumomab tiuxetan radioimmunotherapy for CD20+ B-cell lymphoma: long-term follow-up of a phase 1/2 study. Blood 103: 4429-4431.

30. Huhn D, von Schilling C, Wilhelm M, Ho AD, Hallek M, et al. (2001) Rituximab therapy of patients with B-cell chronic lymphocytic leukemia. Blood 98: 1326-1331.

31. Itälä M, Geisler CH, Kimby E, Juvonen E, Tjonnfjord G, et al. (2002) Standarddose anti-CD20 antibody rituximab has efficacy in chronic lymphocytic leukaemia: results from a Nordic multicentre study. Eur J Haematol 69: 129-134.

32. Morschhauser F, Leonard JP, Fayad L, Coiffier B, Petillon MO, et al. (2009) Humanized anti-CD20 antibody, veltuzumab, in refractory/recurrent nonHodgkin's lymphoma: phase I/II results. J Clin Oncol 27: 3346-3353.
33. Morschhauser F, Marlton P, Vitolo U, Linden O, Seymour JF, et al. (2010) Results of a phase I/II study of ocrelizumab, a fully humanized anti-CD20 mAb in patients with relapsed/refractory follicular lymphoma, Annals of oncology official journal of the European Society for Medical Oncology / ESMO 2: 18701876.

34. Goldenberg DM, Rossi EA, Stein R, Cardillo TM, Czuczman MS, et al. (2009) Properties and structure-function relationships of veltuzumab (hA20), a humanized anti-CD20 monoclonal antibody. Blood 113: 1062-1070.

35. Stein R, Qu Z, Chen S, Rosario A, Shi V, et al. (2004) Characterization of new humanized anti-CD20 monoclonal antibody, IMMU-10, and Its use in combination with the humanized anti-CD22 antibody, epratuzumab, for the therapy of non-Hodgkin's lymphoma. Clin Cancer Res 10: 2868-2878.

36. Teeling JL, French RR, Cragg MS, van den Brakel J, Pluyter M, et al. (2004) Characterization of new human CD20 monoclonal antibodies with potent cytolytic activity against non-Hodgkin lymphomas. Blood 104: 1793-1800.

37. Teeling JL, Mackus WJ, Wiegman LJ, van den Brakel JH, Beers SA, et al (2006) The biological activity of human CD20 monoclonal antibodies is linked to unique epitopes on CD20. J Immunol 177: 362-371.

38. Barth MJ, Hernandez-llizaliturri FJ, Mavis C, Tsai PC, Gibbs JF, et al. (2012) Ofatumumab demonstrates activity against rituximab-sensitive and -resistant cell lines, lymphoma xenografts and primary tumour cells from patients with B-cell lymphoma Br J Haematol 156: 490-498.

39. Baig NA, Taylor RP, Lindorfer MA, Church AK, Laplant BR, et al. (2012) Complement dependent cytotoxicity in chronic lymphocytic leukemia: ofatumumab enhances alemtuzumab complement dependent cytotoxicity and reveals cells resistant to activated complement Leuk Lymphoma 53: 2218-2227.

40. Coiffier B, Lepretre S, Pedersen LM, Gadeberg O, Fredriksen H, et al. (2008) Safety and efficacy of ofatumumab, a fully human monoclonal anti-CD20 antibody, in patients with relapsed or refractory B-cell chronic lymphocytic leukemia: a phase 1-2 study. Blood 111: 1094-1100.

41. Smolej $L$ (2012) Therapy of elderly/comorbid patients with chronic lymphocytic leukemia. Curr Pharm Des 18: 3399-3405.

42. Beum PV, Lindorfer MA, Peek EM, Stukenberg PT, de Weers M, et al. (2011) Penetration of antibody-opsonized cells by the membrane attack complex of complement promotes $\mathrm{Ca}(2+)$ influx and induces streamers. Eur J Immunol 41: $2436-2446$.

43. Hagenbeek A, Gadeberg O, Johnson P, Pedersen LM, Walewski J, et al. (2008) First clinical use of ofatumumab, a novel fully human anti-CD20 monoclonal antibody in relapsed or refractory follicular lymphoma: results of a phase $1 / 2$ trial. Blood 111: 5486-5495.

44. Cang S, Mukhi N, Wang K, Liu D (2012) Novel CD20 monoclonal antibodies for lymphoma therapy. J Hematol Oncol 5: 64.

45. Bowles JA, Wang SY, Link BK, Allan B, Beuerlein G, et al. (2006) Anti-CD20 monoclonal antibody with enhanced affinity for CD16 activates NK cells at lower concentrations and more effectively than rituximab. Blood 108: 2648-2654.

46. Madar R, Novakova E, Baska T (2005) The role of non-critical health-care tools in the transmission of nosocomial infections. BratisI Lek Listy 106: 348-350.

47. Kahl BS, Cheson BD, Friedberg FW (2010) Clinical Roundtable Monograph: current treatment options for $\mathrm{NHL}$ patients refractory to standard therapy: recent data in single-agent and combination therapy. Clinical advances in hematology \& oncology 8: 1-16.

48. van Meerten T, Hagenbeek A (2010) CD20-targeted therapy: the next generation of antibodies. Semin Hematol 47: 199-210.

49. Bello C, Sotomayor EM (2007) Monoclonal antibodies for B-cell lymphomas: rituximab and beyond. Hematology Am Soc Hematol Educ Program .

50. Casulo C, Vose JM, Ho WY, Kahl B, Brunvand M, et al. (2014) A phase I study of PRO1319, a novel anti-CD20 monoclonal antibody in patients with relapsed/ refractory CD20+ indolent NHL: correlation between clinical responses and AUC pharmacokinetics. Clin Immunol 154: 37-46.

51. De Romeuf C, Dutertre CA, Le Garff Tavernier M, Fournier N, Gaucher C, et al. (2008) Chronic lymphocytic leukaemia cells are efficiently killed by an anti-CD20 monoclonal antibody selected for improved engagement of FcgammaRIIIA/CD. Br. J Haematol 140: 635-643.

52. Baritaki S, Militello L, Malaponte G, Spandidos DA, Salcedo M, et al. (2011) The anti-CD20 mAb LFB-R603 interrupts the dysregulated NF-IB/Snail/RKIP/ 
Citation: Singh V, Gupta D, Almasan A (2015) Development of Novel Anti-Cd20 Monoclonal Antibodies and Modulation in Cd20 Levels on Cell Surface: Looking to Improve Immunotherapy Response. J Cancer Sci Ther 7: 347-358. doi:10.4172/1948-5956.1000373

PTEN resistance loop in B-NHL cells: role in sensitization to TRAIL apoptosis. Int J Oncol 38: 1683-1694.

53. Niwa R, Hatanaka S, Shoji-Hosaka E, Sakurada M, Kobayashi Y, et al. (2004) Enhancement of the antibody-dependent cellular cytotoxicity of low-fucose lgG Is independent of FcgammaRIIla functional polymorphism. Clin Cancer Res 10: $6248-6255$

54. Friess T, Gerdes C, Nopora A, Patre M, Preiss S, et al. (2007) GA10, a Nove Humanized Type II CD20 Antibody with Glycoengineered Fc and Enhanced Cell Death Induction, Mediates Superior Efficacy in a Variety of NHL Xenograft Models in Comparison to Rituximab, ASH Annual Meeting Abstracts 110: 2338-2339.

55. Heinrich D, Weinkauf M, Hutter G, Decheva K, Zimmermann Y, et al. (2010) Differential Regulation Patterns of Anti-CD20 Antibodies GA10 and Rituximab in Mantle Cell Lymphoma, ASH Annual Meeting.

56. Herting F, Bader S, Umana P, Klein C (2010) Enhanced activity of GA101, a novel type II, glycoengineered CD20 antibody, in combination with bendamustine or fludarabine, and with the Bcl-2 family inhibitors 1597-1597.

57. Umana P, Moessner E, Bruenker P, Unsin G, Puentener U, et al. (2006) Nove 3rd Generation Humanized Type II CD20 Antibody with Glycoengineered Fc and Modified Elbow Hinge for Enhanced ADCC and Superior Apoptosis Induction.

58. Oflazoglu E, Audoly LP (2010) Evolution of anti-CD20 monoclonal antibody therapeutics in oncology. MAbs 2: 14-19.

59. Robak T (2009) GA-10, a third-generation, humanized and glyco-engineered anti-CD20 mAb for the treatment of B-cell lymphoid malignancies. Curr Opin Investig Drugs 10: 588-596.

60. Bologna L, Gotti E, Manganini M, Rambaldi A, Intermesoli T, et al. (2011) Mechanism of action of type II, glycoengineered, anti-CD20 monoclonal antibody GA10 in B-chronic lymphocytic leukemia whole blood assays in comparison with rituximab and alemtuzumab. J Immunol 186: 3762-3769.

61. Lina MR (2010) Comparison of the cytotoxic mechanisms of anti-CD20 monoclonal antibodies Rituximab and GA10 in Chronic Lymphocytic Leukemia.

62. Dalle S, Reslan L, Besseyre de Horts T, Herveau S, Herting F, et al. (2011) Preclinical studies on the mechanism of action and the anti-lymphoma activity of the novel anti-CD20 antibody GA101. Mol Cancer Ther 10: 178-185.

63. Klein C, Herting F, Friess T, Gerdes C, Nopora A, et al. (2008) GA101, a therapeutic glycoengineered CD20 antibody recognizing a type II epitope mediates outstanding anti-tumor efficacy in non-Hodgkin's lymphoma xenograft models and superior B cell depletion 6: 504 .

64. Mössner E, Brünker P, Moser S, Püntener U, Schmidt C, et al. (2010) Increasing the efficacy of CD20 antibody therapy through the engineering of a new type II anti-CD20 antibody with enhanced direct and immune effector cell-mediated B-cell cytotoxicity. Blood 115: 4393-4402.

65. Dalle S, Reslan L, Manquat SB, Herting F, Klein C, et al. (2008) Compared antitumor activity of GA10 and rituximab against the human RL follicular lymphoma xenografts in SCID beige mice, Blood, Amer Soc Hematology 1900 M Street. NW Suite 200, Washington, Dc 20036 USA 562-562.

66. Umana P, Moessner E, Grau R, Gerdes C, Nopora A, et al. (2008) GA10, a novel human therapeutic type II CD20 antibody with outstanding anti tumor efficacy in non Hodgkins lymphoma xenograft models and superior B cell depletion. Annals of oncology

67. Yang G, Gong P, Xu L, Hunter Z, Zhou Y, et al. (2010) Activity of the CD20 directed monoclonal antibody GA10 relative to rituximab in Waldenstrom's macroglobulinemia (WM), and applicability to patients expressing Fc \{gamma\} RIIIA-158 F/F, ASCO Annual Meeting Proceedings 8112.

68. Lina R, Charles D (2012) Emerging Therapies in Chronic Lymphocytic Leukemia, INTECH Open Access Publishe, USA.

69. Barone D, Burge D, Baum P, Ledbetter J, Hayden-Ledbetter M, et al. (2005) Prolonged depletion of circulating $B$ cells in cynomolgus monkeys after a single dose of TRU-0, a novel CD20 directed therapeutic, Annals of the Rheumatic Diseases. BMJ Publishing Group British Med Assoc House, England.

70. Burge D, Bookbinder S, Kivitz A, Fleischmann R, Shu C, et al. (2007) Phase study of TRU-015, a CD20-directed small modular immunopharmaceutical (SMIPTM) protein therapeutic, in subjects with rheumatoid arthritis. Arthritis research \& therapy $9: 31$.
71. Burge DJ, Bookbinder SA, Kivitz AJ, Fleischmann RM, Shu C, et al. (2008) Pharmacokinetic and pharmacodynamic properties of TRU-0, a CD20-directed small modular immunopharmaceutical protein therapeutic, in patients with rheumatoid arthritis: a Phase I, open-label, dose-escalation clinical study. Clin Ther 30: 1806-1816.

72. Hayden-Ledbetter MS, Cerveny CG, Espling E, Brady WA, Grosmaire LS, et al (2009) CD20-directed small modular immunopharmaceutical, TRU-0, depletes normal and malignant B cells. Clinical cancer research: an official journal of the American Association for Cancer Research 15: 2739-2746.

73. Taylor RP, Lindorfer MA (2008) Immunotherapeutic mechanisms of anti-CD20 monoclonal antibodies. Curr Opin Immunol 20: 444-449.

74. Beers SA, Chan CH, French RR, Cragg MS, Glennie MJ (2010) CD20 as a target for therapeutic type I and II monoclonal antibodies. Semin Hematol 47 107-114

75. Colombat $P$, Brousse N, Morschhauser F, Franchi-Rezgui P, Soubeyran V, et al (2006) Single Treatment with Rituximab Monotherapy for Low-Tumor Burden Follicular Lymphoma (FL): Survival Analyses with Extended Follow-Up (F/Up) of 7 Years

76. Colombat P, Salles G, Brousse N, Eftekhari P, Soubeyran P, et al. (2001) SolalCeligny, Rituximab (anti-CD20 monoclonal antibody) as single first-line therapy for patients with follicular lymphoma with a low tumor burden: clinical and molecular evaluation. Blood 97: 101-106.

77. Cartron G, Zhao-Yang L, Baudard M, Kanouni T, Rouille V, et al. (2008) Granulocyte-macrophage colony-stimulating factor potentiates rituximab in patients with relapsed follicular lymphoma: results of a phase II study. J Clin Oncol, 26: 2725-2731.

78. Zinzani PL, Pulsoni A, Perrotti A, Soverini S, Zaja F, et al. (2004) Fludarabine plus mitoxantrone with and without rituximab versus $\mathrm{CHOP}$ with and without rituximab as front-line treatment for patients with follicular lymphoma. J Clin Oncol 22: 2654-2661.

79. Rummel MJ, Al-Batran SE, Kim SZ, Welslau M, Hecker R, et al. (2005) Bendamustine plus rituximab is effective and has a favorable toxicity profile in the treatment of mantle cell and low-grade non-Hodgkin's lymphoma. J Clin Oncol 23: 3383-3389.

80. Vose JM, Link BK, Grossbard ML, Czuczman M, Grillo-Lopez A, et al. (2001) Phase II study of rituximab in combination with chop chemotherapy in patients with previously untreated, aggressive non-Hodgkin's lymphoma. J Clin Oncol 19: 389-397.

81. Witzig TE, Flinn IW, Gordon LI, Emmanouilides C, Czuczman MS, et al. (2002) Treatment with ibritumomab tiuxetan radioimmunotherapy in patients with rituximab-refractory follicular non-Hodgkin's lymphoma. J Clin Oncol 20: 3262 3269.

82. Chamarthy MR, Williams SC, Moadel RM (2011) Radioimmunotherapy of nonHodgkin's lymphoma: from the 'magic bullets' to 'radioactive magic bullets' Yale J Biol Med 84: 391-407.

83. Witzig TE, Gordon LI, Cabanillas F, Czuczman MS, Emmanouilides C, et al. (2002) Randomized controlled trial of yttrium-90-labeled ibritumomab tiuxetan radioimmunotherapy versus rituximab immunotherapy for patients with relapsed or refractory low-grade, follicular, or transformed B-cell non-Hodgkin's lymphoma. J Clin Oncol 20: 2453-2463.

84. Fisher RI, Kaminski MS, Wahl RL, Knox SJ, Zelenetz AD, et al. (2005) Tositumomab and iodine-13 tositumomab produces durable complete remissions in a subset of heavily pretreated patients with low-grade and transformed non-Hodgkin's lymphomas. J Clin Oncol 23: 7565-7573.

85. Kaminski MS, Tuck M, Estes J, Kolstad A, Ross CW, et al. (2005) 131I-tositumomab therapy as initial treatment for follicular lymphoma. $\mathrm{N}$ Engl J Med 352: 441-449.

86. Leonard JP, Coleman M, Kostakoglu L, Chadburn A, Cesarman E et al. (2005) Abbreviated chemotherapy with fludarabine followed by tositumomab and iodine | 13 tositumomab for untreated follicular lymphoma. J Clin Oncol, 23 : 5696-5704.

87. Davis TA, Kaminski MS, Leonard JP, Hsu FJ, Wilkinson M, et al. (2004) The radioisotope contributes significantly to the activity of radioimmunotherapy. Clin Cancer Res 10: 7792-7798.

88. Wahl RL (2005) Tositumomab and (131)I therapy in non-Hodgkin's lymphoma J Nucl Med 46 Suppl 1: 128S-40S. 
Citation: Singh V, Gupta D, Almasan A (2015) Development of Novel Anti-Cd20 Monoclonal Antibodies and Modulation in Cd20 Levels on Cell Surface: Looking to Improve Immunotherapy Response. J Cancer Sci Ther 7: 347-358. doi:10.4172/1948-5956.1000373

89. Davies AJ (2004) Tositumomab and iodine [1311] tositumomab in the management of follicular lymphoma. An oncologist's view, The quarterly journal of nuclear medicine and molecular imaging: official publication of the Italian Association of Nuclear Medicine 48: 305-316.

90. Roy PS, John S, Karankal S, Kannan S, Pawaskar P, et al. (2013) Comparison of the efficacy and safety of Rituximab (Mabthera) and its biosimilar (Reditux) in diffuse large B-cell lymphoma patients treated with chemo-immunotherapy: A retrospective analysis. Indian journal of medical and paediatric oncology official journal of Indian Society of Medical \& Paediatric Oncology 34: 292-298.

91. Czuczman MS, Fayad L, Delwail V, Cartron G, Jacobsen E, et al. (2012) Ofatumumab monotherapy in rituximab-refractory follicular lymphoma: results from a multicenter study. Blood 119: 3698-3704.

92. Czuczman MS, Hess G, Gadeberg OV, Pedersen LM, Goldstein N, et al (2012) Chemoimmunotherapy with ofatumumab in combination with CHOP in previously untreated follicular lymphoma. Br J Haematol 157: 438-445.

93. Wierda WG, Kipps TJ, Durig J, Griskevicius L, Stilgenbauer S, et al. (2011) Chemoimmunotherapy with O-FC in previously untreated patients with chronic lymphocytic leukemia. Blood 117: 6450-6458.

94. Wayne JL, Ganjoo KN, Pohlman BL, De Vos S, Flinn IW, et al. (2012) Marulappa Efficacy of ocaratuzumab (AME-133v) in relapsed follicular lymphoma patients refractory to prior rituximab.

95. Ganjoo KN, de Vos S, Pohlman BL, Flinn IW, Forero-Torres A, et al. (2015) Phase 1/2 study of ocaratuzumab, an Fc-engineered humanized anti-CD20 monoclonal antibody, in low-affinity FcgammaRIlla patients with previously treated follicular lymphoma. Leuk Lymphoma 56: 42-48.

96. Salles G, Morschhauser F, Lamy T, Milpied N, Thieblemont C, et al. (2012) Phase study results of the type II glycoengineered humanized anti-CD20 monoclonal antibody obinutuzumab (GA101) in B-cell lymphoma patients. Blood 119: 5126-5132.

97. Carlile D, Meneses-Lorente G, Wassner-Fritsch E, Hourcade-Potelleret F, Wenger MK, et al. Pharmacokinetics of obinutuzumab (GA101) in patients with $\mathrm{CD20}+$ relapsed/refractory malignant disease receiving concomitant chemotherapy (Phase lb Study BO21000).

98. Radford J, Davies A, Cartron G, Morschhauser F, Salles G, et al. (2013) Obinutuzumab (GA101) plus CHOP or FC in relapsed/refractory follicular lymphoma: results of the GAUDI study (BO21000). Blood 122: 1137-1143.

99. Cazin B, Lepretre S, Coiffier B, Aurran T, Cartron G (2013) Final results of a multicenter phase IB single agent study with the novel anti-CD20 monoclonal antibody ublituximab (TG-1101) in patients with relapsed chronic lymphocytic leukemia (CLL)[EHA abstract P111]. Haematologica 98: 42.

100. Manshouri T, Do KA, Wang X, Giles FJ, O'Brien SM, et al. (2003) Circulating $\mathrm{CD} 20$ is detectable in the plasma of patients with chronic lymphocytic leukemia and is of prognostic significance. Blood 101: 2507-2513.

101. Lundin J, Osterborg A (2004) Advances in the use of monoclonal antibodies in the therapy of chronic lymphocytic leukemia. Semin Hematol 41: 234-245.

102. Golay J, Lazzari M, Facchinetti V, Bernasconi S, Borleri G, et al. (2001) CD20 levels determine the in vitro susceptibility to rituximab and complement of B-cell chronic lymphocytic leukemia: further regulation by CD55 and CD59. Blood 98: 3383-3389.

103. Tsai PC, Hernandez-llizaliturri FJ, Bangia N, Olejniczak SH, Czuczman MS (2012) Regulation of CD20 in rituximab-resistant cell lines and B-cell nonHodgkin lymphoma. Clinical cancer research 18: 1039-1050.

104.Dancescu M, Wu C, Rubio M, Delespesse G, Sarfati M (1992) IL-4 induces conformational change of CD20 antigen via a protein kinase C-independent pathway. Antagonistic effect of anti-CD40 monoclonal antibody. J Immunol 148: $2411-2416$

105. Sivaraman S, Deshpande CG, Ranganathan R, Huang X, Jajeh A, et al. (2000) Tumor necrosis factor modulates CD 20 expression on cells from chronic lymphocytic leukemia: a new role for TNF alpha? Microsc Res Tech 50: 251-257.

106. Venugopal P, Sivaraman S, Huang XK, Nayini J, Gregory SA, et al. (2000) Effects of cytokines on CD20 antigen expression on tumor cells from patients with chronic lymphocytic leukemia. Leuk Res 24: 411-415.

107. Chow KU, Schneider B, Mitrou PS, Weidmann E (2001) Influence of various cytokines on the expression of CD20 on the surface of CLL-cells in vitro. Leuk Res 25: 99-100.
108. Wojciechowski W, Li H, Marshall S, Dell'Agnola C, Espinoza-Delgado I (2005) Enhanced expression of CD20 in human tumor B cells is controlled through ERK-dependent mechanisms. J Immunol 174: 7859-7868.

109. Gupta D, Crosby ME, Almasan A, Macklis RM (2008) Regulation of CD20 expression by radiation-induced changes in intracellular redox status. Free Radic Biol Med 44: 614-623.

110. Singh V, Gupta D, Arora R, Tripathi RP, Almasan A, et al. (2014) Surface levels of CD20 determine anti-CD20 antibodies mediated cell death in vitro. PLoS One 9: e111113.

111. Karmali R, Larson ML, Wooldridge JE, Gregory SA, O'Brien T, et al. (2011) Granulocyte-macrophage colony stimulating factor-induced immune priming of cyclophosphamide, doxorubicin, vincristine, and prednisone with rituximab chemoimmunotherapy in previously untreated patients with diffuse large B-cel lymphoma and mantle cell lymphoma. Leukemia \& lymphoma 52: 2097-2104.

112. Winiarska M, Bil J, Wilczek E, Wilczynski GM, Lekka M et al. (2008) Statins impair antitumor effects of rituximab by inducing conformational changes of CD20. PLoS medicine 5: e64.

113. Sivaraman S, Venugopal P, Ranganathan R, Deshpande CG, Huang X, et al (2000) Effect of interferon-alpha on CD20 antigen expression of B-cell chronic lymphocytic leukemia. Cytokines Cell Mol Ther 6: 81-87.

114. Winiarska M, Nowis D, Bil J, Glodkowska-Mrowka E, Muchowicz A, et al. (2012) Prenyltransferases regulate CD20 protein levels and influence antiCD20 monoclonal antibody-mediated activation of complement-dependent cytotoxicity. J Biol Chem 287: 31983-31993.

115. Czuczman MS, Olejniczak S, Gowda A, Kotowski A, Binder A, et al. (2008) Acquirement of rituximab resistance in lymphoma cell lines is associated with both global CD20 gene and protein down-regulation regulated at the pretranscriptional and posttranscriptional levels. Clin Cancer Res 14: 1561-1570.

116. Bil J, Winiarska M, Nowis D, Bojarczuk K, Dabrowska-Iwanicka A et al. (2010) Bortezomib modulates surface CD20 in B-cell malignancies and affects rituximab-mediated complement-dependent cytotoxicity. Blood 115: 3745-3755.

117. Hiraga J, Tomita A, Sugimoto T, Shimada K, Ito M et al. (2009) Downregulation of $\mathrm{CD} 20$ expression in B-cell lymphoma cells after treatment with rituximab-containing combination chemotherapies: its prevalence and clinical significance. Blood 113: 4885-4893.

118. Tomita A, Hiraga J, Kiyoi H, Ninomiya M, Sugimoto T, et al. (2007) Epigenetic regulation of CD20 protein expression in a novel B-cell lymphoma cell line, RRBL, established from a patient treated repeatedly with rituximab-containing chemotherapy. Int J Hematol 86: 49-57.

119. Shankar S, Srivastava RK (2008) Histone deacetylase inhibitors: mechanisms and clinical significance in cancer: HDAC inhibitor-induced apoptosis, Advances in experimental medicine and biology 615: 261-298.

120. Shimizu R, Kikuchi J, Wada T, Ozawa K, Kano Y, et al. (2010) HDAC inhibitors augment cytotoxic activity of rituximab by upregulating CD20 expression on lymphoma cells. Leukemia 24: 1760-1768.

121. Singh V, Gupta D, Arora R, Tripathi RP, Almasan A, et al. (2014) Surface levels of CD20 determine anti-CD20 antibodies mediated cell death in vitro. PLoS One 9: e111113.

122. Singh V, Gupta D, Kalra N, Tripathi R (2014) The radiation induced CD20 expression and anti-CD20 antibodies mediated cell death on hematopoietic cancer cell, Proceedings of thirteenth annual meeting of the Society for Free Radical Research-India and international conference on recent trends in free radical and antioxidant research.

123. Kunala S, Macklis RM (2001) lonizing radiation induces CD20 surface expression on human B cells. Int J Cancer 96: 178-181.

124. Mazumder S, Gong B, Almasan A (2000) Cyclin E induction by genotoxic stress leads to apoptosis of hematopoietic cells. Oncogene 19: 2828-2835.

125. Mankaï A, Buhé V, Hammadi M, Youinou P, Ghedira I, et al. (2009) Improvement of rituximab efficiency in chronic lymphocytic leukemia by $\mathrm{CpG}$ mediated upregulation of CD20 expression independently of PU.1. Ann N Y Acad Sci 1173: 721-728.

126. Jilani I, O'Brien S, Manshuri T, Thomas DA, Thomazy VA, et al. (2003) Transient down-modulation of $\mathrm{CD} 20$ by rituximab in patients with chronic lymphocytic leukemia. Blood 102: 3514-3520.

127. Pickartz T, Ringel F, Wedde M, Renz H, Klein A, et al. (2001) Selection of 
Citation: Singh V, Gupta D, Almasan A (2015) Development of Novel Anti-Cd20 Monoclonal Antibodies and Modulation in Cd20 Levels on Cell Surface: Looking to Improve Immunotherapy Response. J Cancer Sci Ther 7: 347-358. doi:10.4172/1948-5956.1000373

B-cell chronic lymphocytic leukemia cell variants by therapy with anti-CD20 monoclonal antibody rituximab. Exp Hematol 29: 1410-1416

128. D'Auria F, Guariglia R, Villani O, Mansueto G, Grieco V, et al. (2010) Modulation of CD20 antigen expression after rituximab treatment: a retrospective study in patients with chronic lymphocytic leukemia. Clin Ther 32: 1911-1916.

129. Lapalombella R, Yu B, Triantafillou G, Liu Q, Butchar JP, et al. (2008) Lenalidomide down-regulates the CD20 antigen and antagonizes direct and antibody-dependent cellular cytotoxicity of rituximab on primary chronic lymphocytic leukemia cells. Blood 112: 5180-5189.
130. Anolik J, Looney RJ, Bottaro A, Sanz I, Young F (2003) Down-regulation of CD20 on B cells upon CD40 activation. Eur J Immunol 33: 2398-2409.

131. Philippé J, Louagie $H$, Thierens H, Vral A, Cornelissen M, et al. (1997) Quantification of apoptosis in lymphocyte subsets and effect of apoptosis on apparent expression of membrane antigens. Cytometry 29: 242-249.

132. Turpaev KT (2002) Reactive oxygen species and regulation of gene expression. Biochemistry (Mosc) 67: 281-292.

133. Buchanan BB, Balmer Y (2005) Redox regulation: a broadening horizon. Annu Rev Plant Biol 56: 187-220. 